\title{
Vancomycinrezisztens Enterococcusok megjelenése sebészeti intenzív osztályon
}

\author{
Szabó Marcell dr. ${ }^{1}$ - Bozó Anna dr. ${ }^{1}$ - Soós Sándor dr. ${ }^{1}$ \\ Darvas Katalin dr. ${ }^{1,2}$ - Harsányi László dr. ${ }^{1}$. Csomós Ákos dr. ${ }^{2}$ \\ Semmelweis Egyetem, Általános Orvostudományi Kar, ${ }^{1}$ I. Sebészeti Klinika, \\ ${ }^{2}$ Aneszteziológiai és Intenzív Terápiás Klinika, Budapest
}

\begin{abstract}
Bevezetés: Az Enterococcusok növekvő antibiotikum-rezisztenciájukkal jelentős kórokozók az intenzív osztályokon; a törzsek új kihívást jelentenek. Célkitüzés: A szerzők célja a Semmelweis Egyetem I. Sz. Sebészeti Klinikájának intenzív osztályán a vancomycinrezisztens törzsek halmozott előfordulása kapcsán szerzett tapasztalok ismertetése. Módszer: Eset-kontroll tanulmányban 2013. január 1. és június 30. közötti időszakban vizsgálták az Enterococcus-incidenciát mikrobiológiai mintákban és a vancomycinrezisztens Enterococcusszal kezelt betegek demográfiai, kórházi tartózkodási, mortalitási adatait. Eredmények: 114 betegnél azonosítottak Enterococcust, közülük 14-nél vancomycinrezisztens törzset. Az Enterococcus-incidencia a vancomycinrezisztens izolátumok megjelenése előtti és utáni időszakok között nem változott. A demográfiai adatokban sem találtak különbséget a két csoport között. A vancomycinrezisztens Enterococcusokat hordozó betegek halálozása meghaladta a vancomycinérzékeny Enterococcusok jelenlétében észleltet ( $42,9 \%$ vs. 30,0\%; $p=0,005$ ), a kórházi tartózkodás ideje azonban nem különbözött. A vancomycinrezisztens csoportban a társbetegségek, valamint az akut mútétek gyakoribbak voltak. Következtetések: A vancomycinrezisztens Enterococcusok jelenlétében észlelhető magasabb halálozás felhívja a figyelmet a megelőzés és infekciókontroll jelentőségére, de a vancomycinrezisztencia oki szerepe kérdéses a nagyobb mortalitásban. Orv. Hetil., 2015, 156(19), 779-784.
\end{abstract}

Kulcsszavak: vancomycin, Enterococcus, vancomycinrezisztens Enterococcus, intenzív, sebészet

\section{Outbreak of vancomycin-resistant enterococci in a surgical intensive care unit}

Introduction: Enterococci have increasing importance in intensive care units, and vancomycin-resistant strains express a new challenge. Aim: The aim of the authors was to present their findings obtained from the first vancomycin-resistant enterococci outbreak occurred in 2013 at the Intensive Care Unit of the 1st Department of Surgery, Semmelweis University. Method: This was a case-control study of patients who had Enterococci species isolated from their microbiological samples between January 1 and June 30, 2013. Changes of Enterococcal incidence and consequences of vancomycin-resistance in patient outcome were analyzed. Demographic data, hospital length of stay and mortality data were also collected. Results: Enterococci were isolated from 114 patients and 14 of them had vancomycinresistant strains. The incidence of Enterococcal strains was not different in the periods before and after the outbreak of the first vancomycin-resistant Enterococci. Patients with vancomycin-resistant Enterococci had significantly higher mortality rate than those with vancomycin-sensitive Enterococcus $(42.9 \%$ vs $30.0 \%, p=0.005)$; however, length of stay was not significantly different. Co-morbidities and emergency surgery were significantly higher in patients who had vancomycin-resistant Enterococci. Conclusions: The higher mortality observed in patients with vancomycinresistant Enterococcus infections highlights the importance of prevention and appropriate infection control, however, the direct relationship of vancomycin-resistance and increased mortality is questionable.

Keywords: vancomycin, enterococcus, vancomycin-resistant enterococcus, intensive care, surgery

Szabó, M., Bozó, A., Soós, S., Darvas, K., Harsányi, L., Csomós, Á. [Outbreak of vancomycin-resistant enterococci in a surgical intensive care unit]. Orv. Hetil., 2015, 156(19), 779-784.

(Beérkezett: 2015. február 6.; elfogadva: 2015. március 19.) 


\section{Rövidítések}

PBP4, -5 = (penicillin binding protein) penicillinkötő fehérje; SOFA $=$ Sequential Organ Failure Assessment; VRE = van comycinrezisztens Enterococcus; VSE = vancomycinérzékeny Enterococcus

A nosocomialis infekciók jelenléte vagy hiánya a betegbiztonság fontos meghatározója. Tudott tény az is, hogy az intenzív osztályokon kezelt betegek halmozottan hordozzák a nosocomialis infekciók ismert rizikófaktorait. Ennek oka, hogy a többszervi elégtelenség okozta súlyos állapot, valamint a kezeléshez szükséges számos invazív eszköz esendővé teszi őket mind a Gram-pozitív, mind a Gram-negatív kórokozókkal szemben [1]. A multirezisztens baktériumok (ideértve az extrém rezisztens és pánrezisztens törzseket is) intenzív osztályos jelenléte változó mértékben, de univerzális jelenség [1, 2, 3], az általuk okozott infekciók sokszor rossz prognózisúak, a halálozás rizikója többszörös lehet [2]. Terjedésük naponta állítja az intenzív osztályos infekciókontrollt komoly feladatok elé, a kezeléshez szükséges antibiotikumok költségvonzatával pedig jelentős anyagi terhet ró az egyes osztályokra.

$\mathrm{Az}$ Enterococcusok (elsősorban E. faecalis és E. faecium) húgyúti, intraabdominalis, seb-, véráramfertőzések, esetenként endocarditisek kórokozói lehetnek. Speciális penicillinkötő fehérjéiknek (PBP4, -5) köszönhető veleszületett cefalosporinrezisztenciájuk mellett gyakori körükben a szerzett rezisztencia egyéb antibiotikumra, például aminopenicillinekre, aminoglikozidokra, esetleges glikopeptidrezisztenciájuk sem új keletú jelenség $[4,5]$. A glikopeptidek elleni védelmet a $\operatorname{van} A$, illetve a $\operatorname{van} B$ rezisztenciagén hordozása biztosítja, utóbbi esetén teicoplaninra a baktériumok érzékenyek maradnak. A vanA-hordozás lényegesen gyakoribb az E. faeciumok körében [4]. Bár az Egyesült Államokban kifejezetten elterjedtek, egyes felmérésekben az E. faeciumok 60\%-a nem érzékeny vancomycinre [6]. Magyarországon a legutóbbi időkig a vancomycinrezisztens Enterococcus törzsek (VRE) nem jelentettek releváns problémát: 2012ben az intenzív osztályokról izolált törzsek csak 0,1\%-a, 2013-ban pedig 0,2\%-a bizonyult rezisztensnek. Aggasztó ugyanakkor, hogy az E. faeciumok között a rezisztens törzsek aránya egy év alatt megnégyszereződött (1,6-ről 6,2\%-ra emelkedett), és több hazai intenzív osztály szembesült a VRE jelentette problémával $[7,8]$. Az E. faecalisok túlnyomórészt megtartották érzékenységüket a vancomycinre, ennek hátterében valószínúleg legalább részben a megszaporodó $C$. difficile-colitisek miatti egyre jelentősebb antibiotikum-nyomás állhat $[9,10]$.

Klinikánk intenzív osztályán a 2013. év elején észleltünk először ilyen izolátumokat, március 25-től április 23-ig halmozottan, ezért járványügyi intézkedések váltak szükségessé. A korábbiakat jelentősen meghaladó VRE-incidencia indokolta, hogy részletesen felmérjük e kórokozók elterjedését, esetleges kóroki, valamint prog- nosztikai jelentőségét, mivel ezzel kapcsolatosan hazai adat ez idáig minimálisan állt rendelkezésre.

Jelen retrospektív, eset-kontroll vizsgálatunkban célunk az volt, hogy elemezzük, a növekvő VRE-incidenciát követi-e az Enterococcusok gyakoriságának változása, a VRE jelenléte pedig milyen kimenetelbeli változással jár együtt a vancomycinre érzékeny Enterococcus (VSE) törzsek hatásával összevetve.

\section{Módszer}

\section{Betegek}

A Semmelweis Egyetem I. Sz. Sebészeti Klinikájának intenzív osztályán 2013. január 1. és június 30. között kezelt betegek adatait tekintettük át. A vizsgálatban azoknak a betegeknek az adatait értékeltük, akiknek a vizsgált időszak során bármely, az intenzív osztályos kezelésükkel összefüggően levett mikrobiológiai mintájukból E. faeci$u m$ vagy $E$. faecalis tenyészett ki. Minden beteget csak egyszer, a legelső tenyésztési eredménnyel szerepeltettünk.

\section{Mikrobiológiai adatok}

A mikrobiológiai adatokat a Semmelweis Egyetem Kórházhigiénés Osztálya összesítve bocsátotta rendelkezésünkre. A VSE- és a VRE-izolátumok elkülönítése fenotípus szerint, antibiogram alapján történt. Kifejeztük az Enterococcus species (VRE és VSE együtt), valamint a VRE-izolátumok gyakoriságát az egyes hónapok során az összes pozitív tenyésztési eredmény arányában. Azonos betegnél észlelt együttes VRE- és VSE-előfordulás esetén a beteg adatait a továbbiakban a VRE-csoportnál vettük figyelembe.

\section{Demográfiai adatok és társbetegségek}

Kigyưjtöttük a betegek nemét, életkorát, a társbetegségeiket (diabetes mellitus, hypertonia, COPD, krónikus veseelégtelenség, malignus betegség), C. difficile társinfekció esetleges jelenlétét, illetve a pozitív tenyésztés napjáig végzett esetleges akut mútétet, a kórházi ápolás hosszát a pozitív tenyésztést megelőzően és követően. Az egyes társbetegségeket anamnézis alapján rögzítettük, illetve a műtét előtti kivizsgálás során frissen felismert eseteket vettük figyelembe. Krónikus veseelégtelenséget $177 \mu \mathrm{mol} / \mathrm{l}$ feletti premorbid kreatininszint esetén vettünk figyelembe. A malignus betegséget, a sebészeti mütétet szükségessé tevő alapbetegségen túl, abban az esetben is dokumentáltuk, ha a beteg a jelen felvételétől függetlenül a megelőző egy évben daganatos betegség miatt kezelést igényelt. C. difficile-infekciót a beválasztás alapjául szolgáló (Enterococcus speciesre) pozitív tenyésztés napjáig levett székletminta (A-toxin) szerológiai vagy tenyésztési eredménye (toxintermelő 
1. táblázat |A két betegcsoport jellemzői, társbetegségeik és az akut műtétek aránya százalékban (zárójelben a betegek száma)

\begin{tabular}{|c|c|c|c|c|c|}
\hline & \multicolumn{2}{|l|}{$\operatorname{VRE}(\mathrm{n}=14)$} & \multicolumn{2}{|c|}{$\operatorname{VSE}(\mathrm{n}=100)$} & $p$ \\
\hline Kor & \multicolumn{2}{|l|}{$68,4 \pm 6,6$ év } & \multicolumn{2}{|c|}{$66,5 \pm 14,0$ év } & 0,089 \\
\hline Férfi & \multicolumn{2}{|l|}{68,8} & \multicolumn{2}{|l|}{52,0} & 0,001 \\
\hline $\mathrm{HT}$ & $(8)$ & 57,1 & $(63)$ & 63,0 & 0,225 \\
\hline $\mathrm{DM}$ & (5) & 36,7 & $(29)$ & 29,0 & 0,139 \\
\hline Szívelégtelenség & (4) & 28,6 & $(17)$ & 17,0 & 0,002 \\
\hline KVE & $(0)$ & 0,0 & $(5)$ & 5,0 & 0,022 \\
\hline COPD & (3) & 21,4 & $(12)$ & 12,0 & 0,004 \\
\hline CDI & $(3)$ & 21,4 & $(8)$ & 8,0 & $<0,001$ \\
\hline Malignus betegség & $(6)$ & 42,9 & $(58)$ & 58,0 & 0,002 \\
\hline Akut mûtét & $(12)$ & 85,7 & $(40)$ & 40,0 & $<0,001$ \\
\hline Megelőző kórházi tartózkodás & \multicolumn{2}{|c|}{14 nap (IQR: 9-19) } & \multicolumn{2}{|c|}{11 nap (IQR: 4-19) } & 0,796 \\
\hline
\end{tabular}

$\mathrm{CDI}=$ C. difficile-infekció; $\mathrm{DM}=$ diabetes mellitus; $\mathrm{HT}=$ hypertonia; $\mathrm{KVE}=$ krónikus veseelégtelenség.

törzs) alapján diagnosztizáltunk. Akut mútétet a felvételt szükségessé tevő akut sebészeti mútét esetén, illetve a pozitív tenyésztés napjáig esetlegesen szükséges sürgős reoperáció esetén dokumentáltunk. Felmértük a kórházi felvétel és a pozitív mikrobiológiai minta levételéig eltelt időt.

\section{Állapotsúlyosság}

A betegek állapotsúlyosságát a Sequential Organ Failure Assesment (SOFA) pontrendszere [11] szerint értékeltük az első VRE-re vagy VSE-re pozitív mikrobiológiai minta levételének napján.

\section{Kimeneteli jellemzők}

Betegeink betegségkimenetelét a beválasztás alapjául szolgáló pozitív tenyésztési eredményt követő kórházi tartózkodásuk időtartamával (napok száma), valamint a 60 napon belüli mortalitás meghatározásával jellemeztük.

\section{Statisztikai elemzés}

Az eredményeket normáleloszlás esetén átlagértékkel és szórással, nem normális eloszlásoknál a medián értékkel, valamint a $25-75 \%$-os interkvartilis tartománnyal, kategoriális változók esetén pedig százalékban adtuk meg. Kategoriális változók megoszlásának összehasonlításához $\chi^{2}$-próbát, normális eloszlású folytonos változók összehasonlításához Student-féle kétmintás t-próbát alkalmaztunk, nem normális eloszlások összevetésére Mann-Whitney-féle U-próbát vettünk igénybe. A statisztikai szignifikancia szintjét $p<0,05$-nál határoztuk meg. Számításainkat webalapú alkalmazás segítségével végeztük el (Wessa, P. 2014, Free Statistics Software, Of- fice for Research Development and Education, version 1.1.23-r7). A mortalitási adatok feltüntetéséhez KaplanMeier szerinti ábrázolást választottunk.

\section{Eredmények}

\section{Populációs jellemzők}

A vizsgált féléves időszakban összesen 295 beteget kezeltünk. A tőlük származó 2062 mikrobiológiai mintát tekintettük át; Enterococcus speciest 114 betegnél azonosítottunk (62 férfi). Közülük 100-nál (51 férfi) VSE volt kimutatható, 14-nél (11 férfi) VRE. Az átlagéletkor a két csoportban hasonlóan alakult, 66,5 $\pm 14,0$ év, illetve $68,4 \pm 6,6$ év volt.

A betegek társbetegségeit a két csoportban az 1 . táblázat mutatja. A hypertonia és a diabetes gyakorisága a két csoportban nem volt szignifikánsan különböző, a többi társbetegségé azonban igen, a krónikus veseelégtelenség, illetve a malignus folyamatok kivételével a VRE-csoportban voltak gyakoribbak a társbetegségek. Külön kiemelendő az akut mútétek lényegesen nagyobb aránya. Az egyes mútéttípusokat a két csoportra bontva a 2. táblázatban összesítettük.

A VSE-t, illetve a VRE-t tartalmazó mikrobiológiai minták anatómiai helyét a 3 . táblázatban mutatjuk be. A VSE-t tartalmazó minták többsége hasi eredetû́ volt $(56,9 \%)$, második helyen a sebek mikrobiológiai leoltásai $(16,3 \%)$, majd pedig a véráram $(7,9 \%)$ szerepelt eredetként. A VRE-k esetében azonban a (sokszor surveillance célból levett) testfelületi minták voltak többségben $(56,4 \%)$, ezeket követték csak az intraabdominalis eredetú $(17,9 \%)$ minták. A kitenyészett VRE-törzsek egy eset kivételével E. faeciumok voltak, mind vancomycinre és teicoplaninra rezisztensnek bizonyultak ( anA-ra jellemző fenotípus). Egy beteg esetében E. faecalist tudtunk 
A két betegcsoportban végzett mútétek megoszlása az érintet szervek szerint, illetve egyes kiemelt típusok aránya százalékban (zárójelben a betegek száma)

\begin{tabular}{lll|ll}
\hline & \multicolumn{2}{l|}{ VRE } & VSE & \\
\hline Nyelőcső & $(2)$ & 14,3 & $(5)$ & 5,2 \\
Gyomor & $(2)$ & 14,3 & $(14)$ & 14,6 \\
Máj és epeút & $(2)$ & 14,3 & $(20)$ & 20,8 \\
Hasnyálmirigy & $(2)$ & 14,3 & $(10)$ & 10,4 \\
Cholecystectomia & $(2)$ & 14,3 & $(5)$ & 5,2 \\
Vékonybél & $(2)$ & 14,3 & $(2)$ & 2,1 \\
Végbél- és vastagbél & $(1)$ & 7,1 & $(21)$ & 21,9 \\
Appendectomia & $(0)$ & 0,0 & $(1)$ & 1,0 \\
Egyéb intraperitonealis & $(0)$ & 0,0 & $(14)$ & 14,6 \\
Testfelület & $(0)$ & 0,0 & $(2)$ & 2,1 \\
Amputáció & $(1)$ & 7,1 & $(2)$ & 2,1 \\
\hline
\end{tabular}

3. táblázat |A pozitív mikrobiológiai minták eredetének megoszlása száza lékban az egyes testtájak szerint (zárójelben a betegek száma)

\begin{tabular}{lll|ll}
\hline Hely & \multicolumn{2}{l|}{ VRE } & VSE \\
\hline Has & $(7)$ & 17,9 & $(136)$ & 56,9 \\
Húgyút & $(4)$ & 10,3 & $(10)$ & 4,2 \\
Légút & $(5)$ & 12,8 & $(5)$ & 2,1 \\
Kanül & $(0)$ & 0,0 & $(14)$ & 5,9 \\
Véráram & $(1)$ & 2,6 & $(19)$ & 7,9 \\
Seb & $(1)$ & 2,6 & $(39)$ & 16,3 \\
Testfelület & $(21)$ & 53,8 & $(12)$ & 5,0 \\
Pleura & $(0)$ & 0,0 & $(4)$ & 1,7 \\
\hline
\end{tabular}

kimutatni, vanB-re jellemző fenotípussal, teicoplaninra megtartott érzékenységgel.

A betegek mintavételt megelőző kórházi tartózkodása nem különbözött szignifikánsan, a VSE-csoportban 11 nap (IQR: 4-19), a VRE-csoportban 14 nap (IQR: 9-19) volt $(p=0,796)$.

\section{Az Enterococcus- és a VRE-gyakoriság változása}

A vizsgált féléves időszakban az összes pozitív tenyésztési eredmény arányában az egyes hónapok során a VREgyakoriság jelentős változásokat mutatott (1. ábra). A VRE-k aránya március és április hónapokban kifejezetten emelkedett volt, akkor 3,4\%, illetve 4,9\% volt az öszszes pozitív tenyésztési eredmény százalékában. Március 25-től április 23-ig járványügyi intézkedések váltak szükségessé: izolációs részleget alakítottunk ki az intenzív osztályon, illetve a már onnan kihelyezhetô állapotú betegek számára a sebészeti osztályon. Rendszeresen végeztük a kontakt betegek szûrését. 2013. április 2-ától 23-áig saját hatáskörben elrendelt felvételi zárlat volt az intenzív osztályon, ezzel egy időben a műtőblokk terüle-

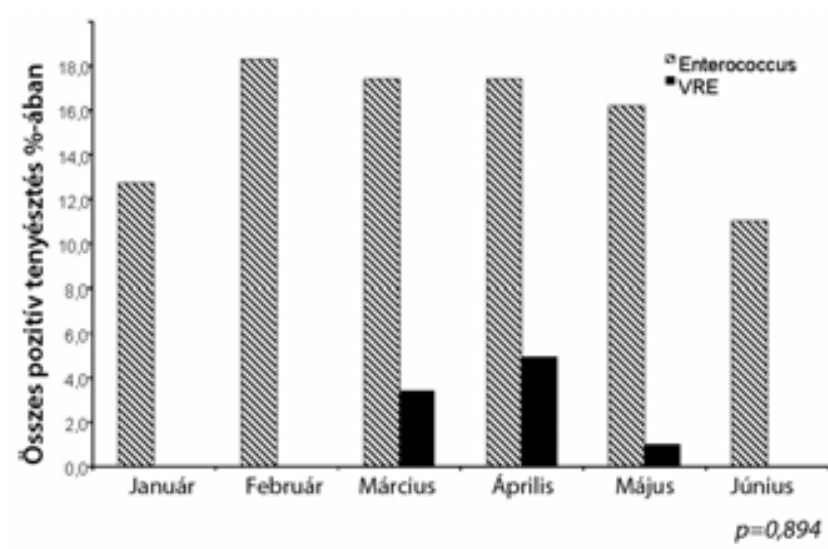

\begin{tabular}{l|l} 
1. ábra & Az Enterococcusok és a VRE-k aránya az egyes hónapokban az
\end{tabular} összes pozitív tenyésztés arányában

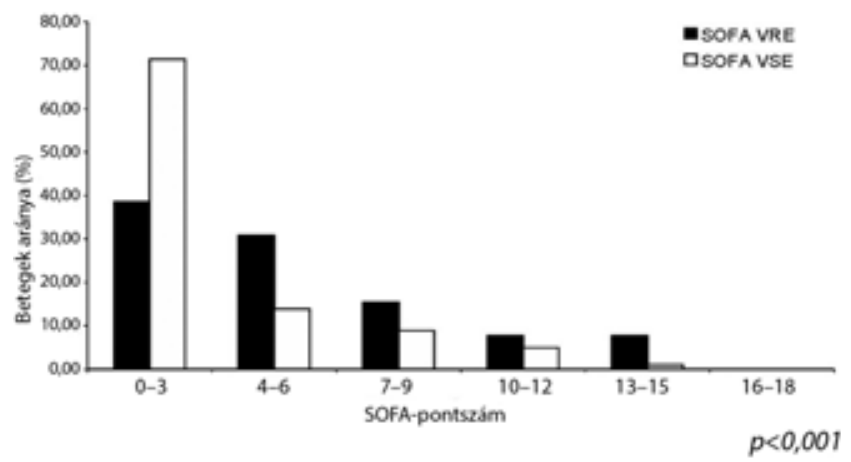

2. ábra $\mid$ A VRE- és a VSE-betegcsoport SOFA-pontszám szerinti megoszlása

tén ideiglenes posztoperatív intenzív részleget hoztunk létre csökkentett ágyszámmal. Az Enterococcus speciesek aránya a vizsgált hónapokban a levett mintákból kitenyészett baktériumok 11,0-18,3\%-át tette ki. A járványos halmozódást megelőző (2013. január l-jétől március 25-éig) és az azt magában foglaló (2013. március 26-ától június 30-áig) időszak adatait összevetve, a VRE-gyakoriság változása szignifikánsnak bizonyult, de a VRE halmozódása nem hozta magával az Enterococcusok hasonló mértékû elszaporodását az intenzív osztályon kezelt betegek körében (Enterococcusok: $p=0,809$; VRE: $p<0,001)$.

\section{Vancomycinrezisztencia és állapotsúlyosság}

A 2. ábrán mutatjuk be a VSE-vel, illetve VRE-vel érintett betegek SOFA-pontszám szerint képzett csoportok közötti megoszlását. A VSE-vel kapcsolatba került betegek legnagyobb része az alacsony (0-3) SOFA-ponttal jellemezhető csoportba tartozott. Ezzel szemben a VRE-s betegek szignifikánsan nagyobb arányban tartoztak a magasabb állapotsúlyosságú csoportokba. 


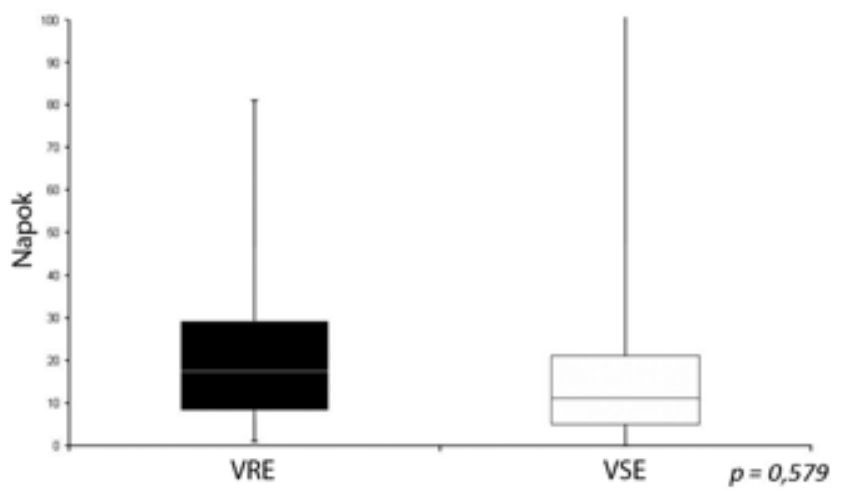

3. ábra | Kórházi tartózkodás napjai

\section{Kimeneteli jellemzők}

\section{Kórházi tartózkodás}

A VSE-csoport medián kórházi tartózkodása 22 nap (15-42), míg a VRE-csoportban 33 nap volt (24-47) (3. ábra). A különbség a statisztikai szignifikancia szintjét nem érte el $(p=0,942)$.

\section{Halálozás}

Betegeink kórházi halálozását a bevonás alapját képező pozitív tenyésztési eredményt követô 60 . napig ábrázoljuk a 4. ábrán látható Kaplan-Meier-görbén. A VREcsoportban 6, a VSE-csoportban 31 beteg halt meg, ez $42,9 \%$-nak, illetve $31,0 \%$-nak felelt meg $(p=0,010)$.

\section{Megbeszélés}

Az intenzív osztályokon szerzett nosocomialis infekciók negatív hatása a betegségkimenetelre vitathatatlan, és közismert az is, hogy nagy hányaduk multirezisztens kórokozóktól származik. A kórokozó nagymértékű antibiotikum-rezisztenciája (együttesen figyelembe véve a multirezisztens és extrém rezisztens törzseket), mint önálló rizikófaktor azonban már kevésbé egyértelmű. Bár az nem lehet kérdéses, hogy az elkerülhető nosocomialis infekció veszélyt jelent a kritikus állapotú betegekre, an-

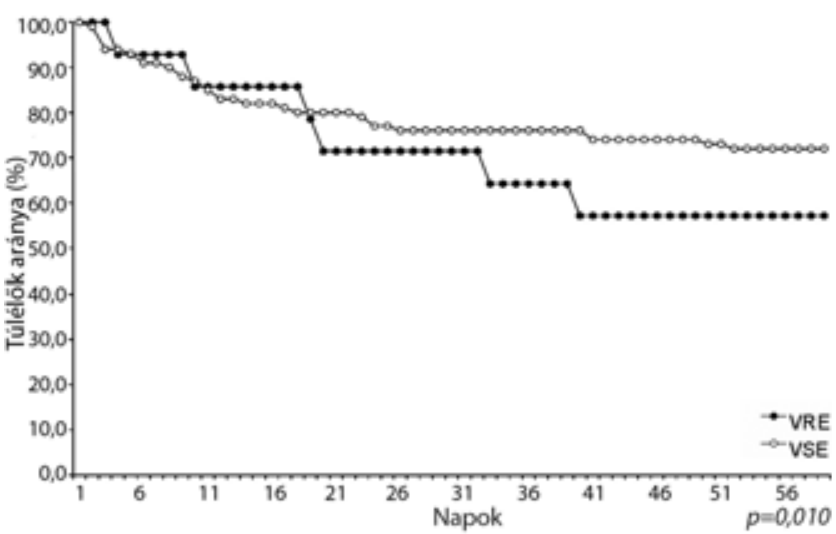

4. ábra napok szerint nak megítélése, hogy az intenzív osztályon szerzett infekció prognózisa mennyiben változik az egyes kórokozók és azok rezisztenciáinak megléte vagy hiánya esetén, már külön-külön vizsgálandó [12]. Nehéz megítélni azt is, hogy önmagában a multirezisztens kórokozó akvirálása fokozza-e a mortalitást, vagy a nagyobb állapotsúlyosságú betegek hajlamosabbak inkább ilyen infekciókra, más szóval, a kórokozó megléte inkább az állapotsúlyosság egy újabb markere, amely a rosszabb kimenetelt prognosztizálja. A már idézett közleményben Lambertés munkatársai által bemutatott erôs bizonyítékok alapján több kórokozó (S. aureus, $P$. aeruginosa, E. coli) esetében a nagymértékű antibiotikum-rezisztencia önálló mortalitásnövelő szerepét egyértelmúnek tekinthetjük [2].

$\mathrm{Az}$ Enterococcus speciesek esetében a helyzet kevésbé világos [13, 14]. Hazai közlemények, illetve tapasztalatok e baktériumcsoport esetében nem állnak rendelkezésre. Saját vizsgálatunkat a VRE sajnálatos, az országos átlagot meghaladó mértékű [8], járványszerü - bár viszonylag rövid ideig tartó - halmozódása tette lehetővé. Arra a kérdésünkre, hogy a vancomycinrezisztens törzsek megjelenése fokozza-e az Enterococcusok együttes intenzív osztályos jelenlétét, vizsgálatunk nemleges választ adott, mivel a vizsgálat során nem észleltünk szignifikáns mértékû változást a gyakoriságukban a pozitív bakteriológiai minták között.

A VRE és a VSE jelenléte esetén a pozitív minta levétele napján már észlelhető volt bizonyos különbség az állapotsúlyosságban, a VRE-csoport betegei ugyanis nagyobb arányban tartoztak a magasabb állapotsúlyosságú (magasabb SOFA-értékkel jellemezhető) csoportokba. A kimenetelt jellemző paraméterek közül a kórházi tartózkodás ideje nem különbözött érdemben, a halálozás azonban szignifikánsan volt magasabb a VRE-csoportban. Bár ez a megfigyelés mindenképpen figyelemre méltó, azonban nem alkalmas a VRE önálló kóroki szerepének tisztázására, különösen, ha figyelembe vesszük, hogy a VRE-izolátumok nagyobb arányban származtak testfelületi, így vélhetően kolonizáló flórát tartalmazó mintákból, mint a VSE-k. A magasabb mértékü mortalitás lehet a VRE-vel kezelt betegek körében gyakoribb társbetegségek következménye, illetve a közöttük gyakoribb akut sebészeti beavatkozást igénylő helyzetek velejárója is.

Vizsgálatunk hátránya az alacsony esetszám és a retrospektív elemzés. Ezzel a metodikával nem tudtuk elkülöníteni a VRE okozta kolonizációt és a fertőzést, emiatt szükségesnek gondoljuk a jövőben prospektív vizsgálatok végzését.

A C. difficile elterjedtsége miatti fokozódó intenzív osztályos glikopeptidhasználat hazánkban is előrevetíti a vancomycinrezisztens Gram-pozitív baktériumok terjedését, saját tapasztalatunk is megfelelt ennek; VRE-vel azonosított betegeink között magasabb volt a $C$. difficile okozta infekciók aránya, mint a VSE-csoportban. Tekintettel az ilyenkor jelentősen beszúkült eszköztárra (linezolid, amely jelenleg hazánkban csak egyedi import útján 
szerezhető be, illetve a nagy költségvonzatú tigecyclin), már a jelen közlemény adatai alapján is kiemelendő a megfelelő intenzív osztályos infekciókontroll jelentősége.

Anyagi támogatás: A cikk megírása anyagi támogatásban nem részesült.

Szerzôi munkamegosztás: Sz. M.: A hipotézisek kidolgozása, a vizsgálat szervezése, statisztikai elemzés, a kézirat szövegezése. Cs. Á.: A hipotézisek kidolgozása, irányító javaslatok a kézirat szövegezésére. B. A., S. S.: Részvétel a vizsgálatokban, releváns klinikai adatok gyüjtése. D. K., H. L.: Irányító javaslatok a kézirat szövegezésére. H. L.: $\mathrm{Az}$ idézett járványügyi intézkedések saját hatáskörü elrendelése, tanácsok a további tudományos célú feldolgozáshoz. A cikk végleges változatát valamennyi szerző elolvasta és jóváhagyta.

Érdekeltségek: A szerzőknek nincsenek érdekeltségeik

\section{Köszönetnyilvánítás}

A közlemény szerzői itt fejezik ki hálájukat $d r$. Antmann Katalin föorvosnőnek, a Semmelweis Egyetem Kórházhigiénés Osztálya vezetőjének, amiért rendelkezésünkre bocsátotta összesített mikrobiológiai adatbázisát, valamint a járványügyi vizsgálatok dokumentációját.

\section{Irodalom}

[1] Hanberger, H., Arman, D., Gill, H., et al.: Surveillance of microbial resistance in European intensive care units: a first report from the Care-ICU programme for improved infection control. Intensive Care Med., 2009, 35(1), 91-100.

[2] Lambert, M. L., Suetens, C., Savey, A., et al.: Clinical outcomes of health-care-associated infections and antimicrobial resistance in patients admitted to European intensive-care units: a cohort study. Lancet Infect. Dis., 2011, 11(1), 30-38.

[3] Tabah, A., Koulenti, D., Laupland, K., et al.: Characteristics and determinants of outcome of hospital-acquired bloodstream in fections in intensive care units: the EUROBACT International Cohort Study. Intensive Care Med., 2012, 38(12), 1930-1945.

[4] Hollenbeck, B. L., Rice, L. B.: Intrinsic and acquired resistance mechanisms in enterococcus. Virulence, 2012, 3(5), 421-433.
[5] Leclercq, R., Derlot, E., Duval, J., et al.: Plasmid-mediated resistance to vancomycin and teicoplanin in Enterococcus faecium. N. Engl. J. Med., 1988, 319(3), 157-161.

[6] Wisplinghoff, H., Bischoff, T., Tallent, S. M., et al.: Nosocomial bloodstream infections in US hospitals: analysis of 24,179 cases from a prospective nationwide surveillance study. Clin. Infect. Dis., 2004, 39(3), 309-317.

[7] NBS Annual reports. National Center for Epidemiology: Results of antibiotics resistance obtained from microbiologic surveillance in Hungary. [Nemzeti Bakteriológiai Surveillance Adatfeldolgozó Csoport. A magyarországi mikrobiológiai surveillance antibiotikum rezisztencia eredményei.] Országos Epidemiológiai Központ, Budapest, 2012. [Hungarian]

[8] NBS Annual reports. National Center for Epidemiology: Results of antibiotics resistance obtained from microbiologic surveillance in Hungary. [Nemzeti Bakteriológiai Surveillance Adatfeldolgozó Csoport. A magyarországi mikrobiológiai surveillance antibiotikum rezisztencia eredményei.] Országos Epidemiológiai Központ, Budapest, 2013. [Hungarian]

[9] Al-Nassir, W. N., Sethi, A. K., Li, Ү., et al.: Both oral metronidazole and oral vancomycin promote persistent overgrowth of vancomycin-resistant enterococci during treatment of Clostridium difficile-associated disease. Antimicrob. Agents Chemother., 2008, 52(7), 2403-2406.

[10] Sethi, A. K., Al-Nassir, W. N., Nerandzic, M. M., et al.: Skin and environmental contamination with vancomycin-resistant enterococci in patients receiving oral metronidazole or oral vancomycin treatment for Clostridium difficile-associated disease. Infect. Control Hosp. Epidemiol., 2009, 30(1), 13-17.

[11] Vincent, J. L., Moreno, R., Takala, J., et al.: The SOFA (Sepsisrelated Organ Failure Assessment) score to describe organ dysfunction/failure. On behalf of the Working Group on SepsisRelated Problems of the European Society of Intensive Care Medicine. Intensive Care Med., 1996, 22(7), 707-710.

[12] Vincent, J. L.: Does microbial resistance matter? Lancet Infect. Dis., 2011, $11(1), 3-4$.

[13] Cheah, A. L., Spelman, T., Liew, D., et al.: Enterococcal bacteraemia: factors influencing mortality, length of stay and costs of hospitalization. Clin. Microbiol. Infect., 2013, 19(4), E181-E189.

[14] Cheah, A. L., Spelman, T., Peel, T., et al.: Impact of vanB vancomycin-resistant enterococcal bacteraemia analysed as a time-varying covariate on length of hospital stay. Epidemiol. Infect., 2014, $142(12), 2667-2671$.

(Szabó Marcell dr., Budapest, Üllői út 78., 1082 e-mail: szabo.marcell86@gmail.com) 